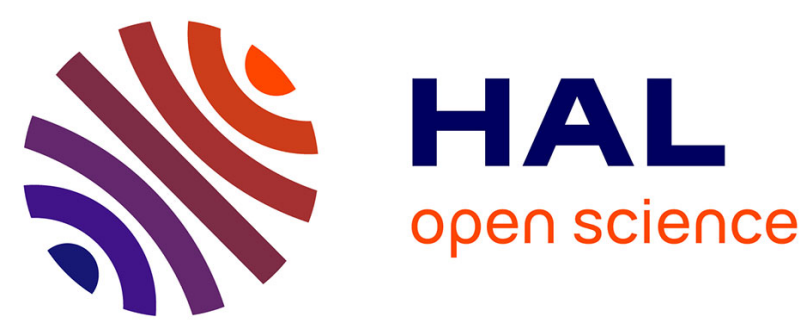

\title{
Experimental Determination of Hydrodynamic Properties of Weathered Granite
}

Matthieu M. Rouxel, Laurent L. Ruiz, Jérôme Molenat, Yannick Y. Hamon, Gaëtane G. Chirié, Didier Michot

\section{- To cite this version:}

Matthieu M. Rouxel, Laurent L. Ruiz, Jérôme Molenat, Yannick Y. Hamon, Gaëtane G. Chirié, et al.. Experimental Determination of Hydrodynamic Properties of Weathered Granite. Vadose Zone Journal, 2012, 11 (3), 10 p. 10.2136/vzj2011.0076 . hal-01001294

\section{HAL Id: hal-01001294 \\ https://hal.science/hal-01001294}

Submitted on 4 Jun 2014

HAL is a multi-disciplinary open access archive for the deposit and dissemination of scientific research documents, whether they are published or not. The documents may come from teaching and research institutions in France or abroad, or from public or private research centers.
L'archive ouverte pluridisciplinaire HAL, est destinée au dépôt et à la diffusion de documents scientifiques de niveau recherche, publiés ou non, émanant des établissements d'enseignement et de recherche français ou étrangers, des laboratoires publics ou privés. 


\section{Original Research}

M. Rouxel

L. Ruiz*

J. Molénat

Y. Hamon

G. Chirié

D. Michot

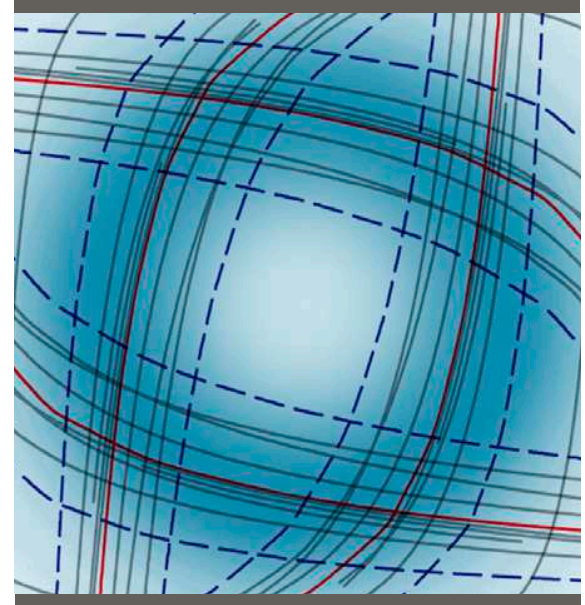

This paper presents water-retention

curves of weathered granite. They

differ from those estimated with

pedotransfer functions and from

those reported for other granites

with the same weathering index.

There is a need to develop a data-

base of retention properties of

weathered bedrocks and a classifi-

cation more appropriate than the

weathering index.

M. Rouxel, L. Ruiz, Y. Hamon, G. Chirié, and D. Michot, INRA, UMR1069 Sol Agro et hydrosystème Spatialisation, F-35000 Rennes

France; L. Ruiz, Y. Hamon, G. Chirié, and

D. Michot, Agrocampus Ouest, UMR1069

Sol Agro et hydrosystème Spatialisation,

F-35000 Rennes, France; J. Molénat, INRA,

LISAH, UMR INRA-IRD-SupAgro, 2 place

Viala, 34060 Montpellier, France; and D.

Michot, Univ. Européenne de Bretagne,

35000 Rennes, France. *Corresponding

author (Laurent.Ruiz@rennes.inra.fr).

Vadose Zone J.

doi:10.2136/vzj2011.0076

Received 30 June 2011.

Open Access Article.

(C) Soil Science Society of America

5585 Guilford Rd., Madison, WI 53711 USA.

All rights reserved. No part of this periodical may be reproduced or transmitted in any form or by any means, electronic or mechanical, including photocopying, recording, or any information storage tocopying, recording, or any information storage from the publisher.

\section{Experimental Determination of Hydrodynamic Properties of Weathered Granite}

Weathering processes transform hard fresh rock into regolith materials, composed of weathered bedrock and soils. The thickness of the weathered bedrock layer varies greatly, attaining several meters under certain climatic and lithologic conditions. The hydrology of catchments on bedrock is strongly controlled by the hydrologic functioning of these weathered bedrock layers, and the understanding and modeling of this functioning requires a knowledge of their hydraulic properties, such as their water retention curves. There are few references available on the water retention curve of weathered bedrock. To fill this gap, we measured the water retention characteristic of highly weathered Plomelin leucogranodiorite in replicate core samples. The study of weathered granite samples showed that their mean water retention curves differed significantly from those estimated for soil samples of the same grain size distribution using a pedotransfer function and for other granites with the same weathering index. Even if one can generate hypotheses to explain the observed differences, the three approaches we used to compare our results cannot replace the experimental approach to generate the water retention curve of a material such as weathered granite. In addition to enriching the body of work on water retention curves of weathered bedrocks, the results of this work suggest that there is a need for developing a database of retention properties of weathered bedrocks in parallel with the development of a model based on factors more appropriate than the weathering index.

Abbreviations: PSD, particle size distribution.

Weathering processes transform hard fresh rock into regolith materials, composed of weathered bedrock (saprolite, saprock) and soils (Graham et al., 2010). The thickness of the weathered bedrock layer varies greatly, attaining several meters under certain climatic and lithologic conditions. Recent studies on catchment hydrology have shown that weathered bedrocks play an important role in hydrologic and hydrochemical processes (Haria and Shand, 2004; Legout, 2006; Martin et al., 2004; Molénat, 2008; Rouxel et al., 2011) and thus in the transport of dissolved substances. In fact, weathered bedrock can store large quantities of water, influencing flows during low-water periods and constituting, along with the soil, a water reserve for tree growth (Graham et al., 2010; Hubbert et al., 2001a; Kew and Gilkes, 2006; Ruiz et al., 2010; Schwinning, 2010).

The groundwater that develops in weathered bedrock aquifers responds strongly to rainfall and has annual water-level amplitudes of several meters (Legout et al., 2007; Martin et al., 2006; Molénat et al., 2005; Rouxel et al., 2011). Because of this, the water contents of weathered bedrock aquifers are highly variable, from saturation to contents below water-holding capacity. Consequently, understanding and modeling the hydrologic functioning of weathered bedrock requires knowing their hydrodynamic properties both when completely saturated (hydraulic conductivity, total porosity) and when partially saturated (retention curve, curve of the decrease in hydraulic conductivity). Few studies (and therefore few references) exist regarding the unsaturated hydrodynamic properties of weathered bedrock (Hubbert et al., 2001b; Johnson-Maynard et al., 1994; Jones and Graham, 1993; Katsura et al., 2006, 2009; Kew and Gilkes, 2006).

To measure the hydrodynamic properties of weathered bedrock, two solutions are theoretically possible. The first is based on methods specific to samples of solid rock, i.e., the transient-pulse method (Brace et al. 1968), gas permeability (reviewed by Neuzil, 1986), or Hg intrusion porosimetry (Lin et al., 1999, cited by Katsura et al., 2006) to measure their hydrodynamic properties. But these methods are not suitable for samples of highly weathered bedrock. The second solution is to use soil science methods. From a textural and structural point of view, a highly weathered bedrock behaves much like a soil. Consequently, soil science methods 
(gravimetric water content measurement associated with pressure plate equipment, pressure chamber equipment, or microtensiometers under drying conditions) appear better able to take the hydrodynamic properties of these materials into account. Nonetheless, the ability of soil science methods to measure the hydrodynamic properties of weathered bedrock has, to our knowledge, been little studied.

To avoid applying direct measures on samples, pedotransfer functions constitute an approach also used in soil science to derive the properties of a soil, such as its hydrodynamic properties under partially saturated conditions, from its basic properties. These pedotransfer functions have been constructed from databases containing field and laboratory measurements of different types of soil. Gravelly soils, or in general those with coarse fragments, are rarely studied because measuring their water-retention properties is methodologically difficult. Nonetheless, currently developed pedotransfer functions could be suitable for estimating the hydrodynamic properties of weathered bedrock.

Weathering processes transform hard fresh rock (e.g., granite) into weathered bedrock with greatly increased porosity (Fig. 1). Graham et al. (2010) described the mechanisms and implications of transforming nonporous hard rock into porous regolith.

A variety of methods have been proposed to quantify the degree of weathering of igneous rocks using quantitative criteria (Gokceoglu et al., 2009). To our knowledge, however, these approaches have never been used to relate the degree of weathering to hydrodynamic properties. To date, studies of water retention curves of weathered granite have used a qualitative approach proposed in the classification system of Clayton and Arnold (1972).

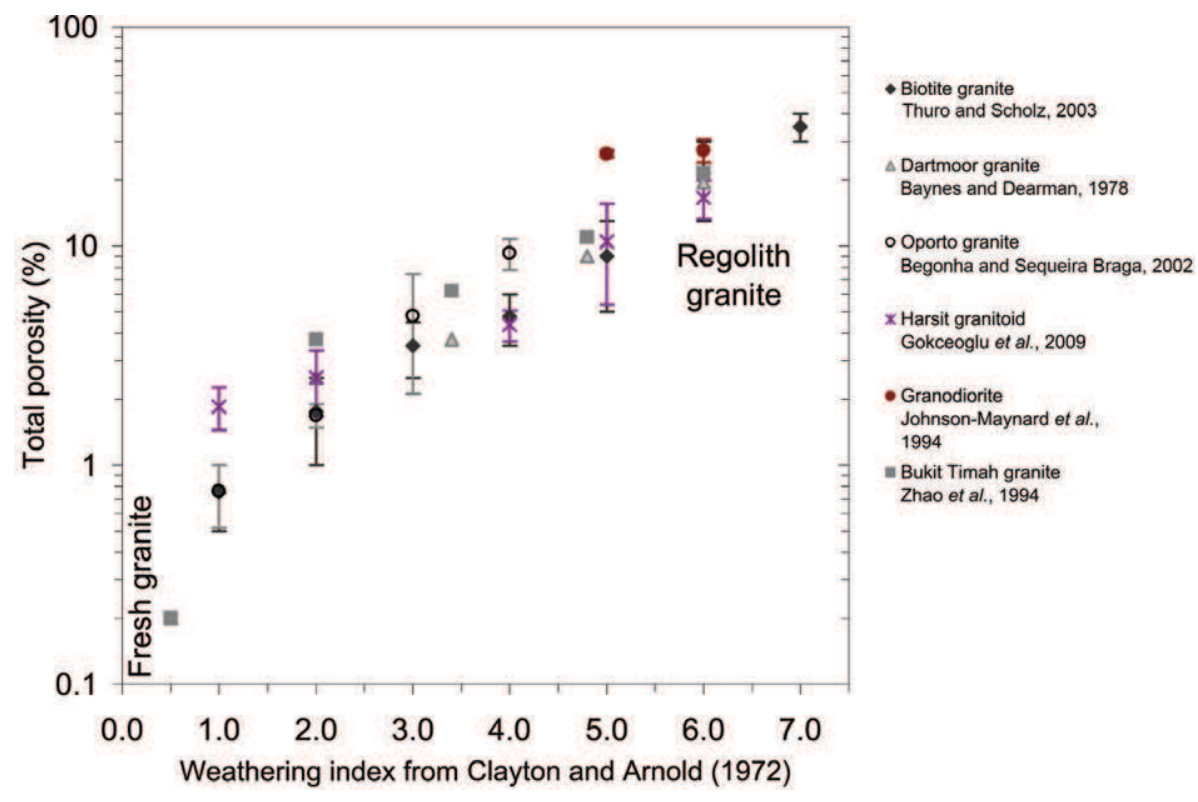

Fig. 1. Relation between the porosity of some granites and weathering class. Porosity of an undisturbed granite ranges from 0.02 to $1.80 \%$.
The objective of this study was to determine experimentally the mean retention properties (retention curve) of a weathered granite. With a view toward deriving the retention properties of weathered granite from properties more easily measured, we studied the suitability of pedotransfer functions classically used for soils and the pertinence of a weathering index as auxiliary measures to estimate the retention properties of weathered granite. Ultimately, it is a matter of better understanding the properties of weathered bedrocks and the means to estimate them.

\section{Materials and Methods Site Description and Weathered Granite Characteristics}

The site is located in southwestern Brittany (2347.35 N, 117.52 E). It has belonged to the French network of environmental observatories (Observatoire de Recherche en Environnement) since 2002 (http:// www.inra.fr/ore_agrhys_eng/). The site has an elevation of $33 \mathrm{~m}$ above sea level. The climate is oceanic. The mean annual temperature is $11.4^{\circ} \mathrm{C}$, with a minimum of $6.1^{\circ} \mathrm{C}$ in January and a maximum of $17.6^{\circ} \mathrm{C}$ in July. The mean annual rainfall and potential evapotranspiration for the last decade are $1167 \pm 195$ and $616 \pm 71 \mathrm{~mm}$, respectively.

The soils at the site are sandy loam (distric cambisol, FAO classification). The upper horizon $(0-20 \mathrm{~cm})$ is rich in organic matter (4.5-6\%). The soil depth was surveyed throughout the site, and the average value is $0.8 \mathrm{~m}$. Soils are well drained except in the relatively narrow bottomlands, where hydromorphic soils are found. The bedrock is a fissured and fractured granite (leucogranodiorite of Plomelin, Paleozoic; Béchennec et al., 1999), overlain by weathered granite. Weathering of minerals in the granite has resulted in the formation of secondary minerals consisting mostly of clay. Chemical alteration of minerals involving disaggregation of quartz grains and the redistribution of clay and silt has produced a characteristic sandy to clayed layer.

From a pedologic pit in the same site, Legout (2006) described five weathered granite types with different degrees of weathering and found that different types can be intermingled across short distances at the same depth. At depth, based on an electrical resistivity tomography survey, Cosenza (2005) proposed a three-dimensional model including several structures, in particular a network of sealed fractures and unweathered granite boulders.

The average depth of the weathered granite layer was estimated to be $20 \mathrm{~m}$ (Legchenko et al., 2004), and the unconfined aquifer corresponds to this layer. The water table 
reacts quickly to recharge events, within a few hours after rain events of more than several millimeters (Legout et al., 2007; Martin et al., 2004). Upslope, the permanently unsaturated zone is 2 to $3 \mathrm{~m}$ deep, and Legout et al. $(2005,2007)$ showed that this layer determines time transfer and is a medium for biogeochemical reactions.

Observations have shown that the weathered granite is permeated by a continuous network of mesofractures (Legout, 2006; Legout et al., 2005). It maintains the original rock texture but is friable and can be crumbled by hand into its individual grains. Feldspars are powdery and weathered to clay minerals, while biotite appears silver and has weakly visible joints. The scheme developed by Clayton and Arnold (1972) was used to classify the weathered granite samples by weathering index. This qualitative description corresponds to Index 6 in the Clayton and Arnold classification or very well weathered granite. The mesofracture network in weathered granite opens up the rock mass to extensive percolation of water.

\section{Weathered Granite Sampling}

Ten samples were extracted using stainless steel cylinders $15 \mathrm{~cm}$ in diameter and $7 \mathrm{~cm}$ tall (Fig. 2). Samples were taken from depths of 130 to $170 \mathrm{~cm}$ in a pit $2 \mathrm{~m}$ deep on a plateau area (Fig. 3). The cylinders were inserted vertically in a flat zone thanks to a cylinder holder with a hammering head and using a no-rebound hammer provided by the Wind equipment supplier (SDEC France). Samples were taken from

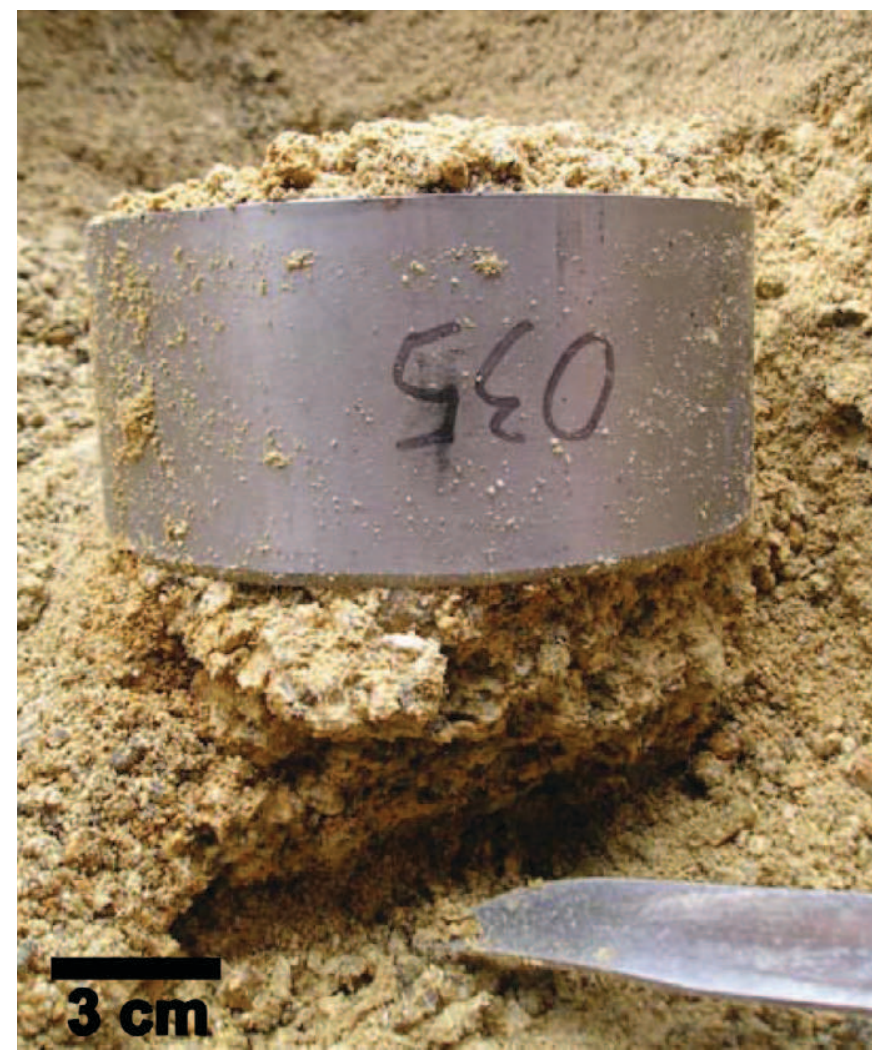

Fig. 2. A weathered granite sampler $155 \mathrm{~cm}$ below the soil surface with a $15-\mathrm{cm}$ (inside diameter) cylinder.

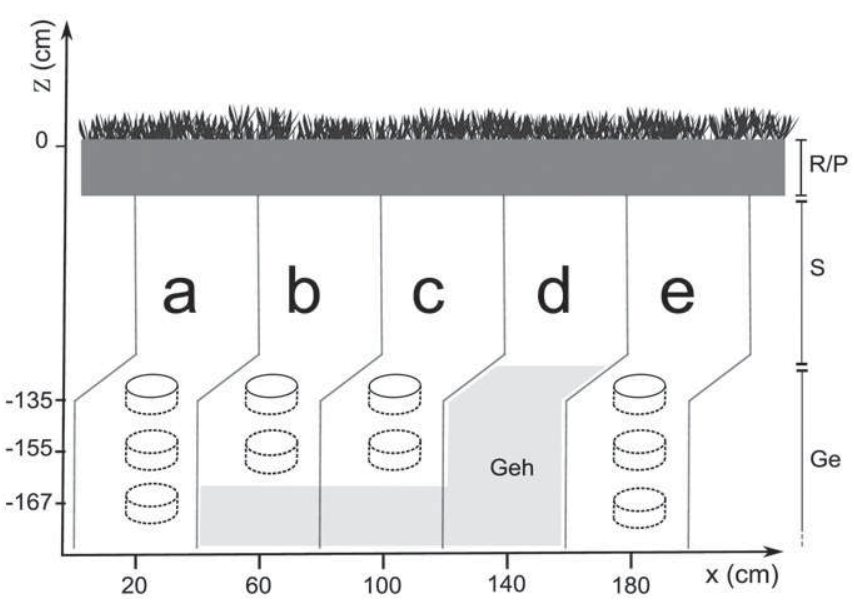

Fig. 3. Configuration of the sampling trench section: R, the shallow root zone; P, plow layer; $S$, structural horizon with deep roots; $\mathrm{Ge}$, weathered granite with both homogeneous color and structure; Geh, weathered granite with heterogeneous blocks. Cylinders show the core sample positions. Letters $a$ to $e$ correspond to the pit crosssections. The bent vertical lines suggest the width of the trench, with the horizontal zone where sampling cylinders were inserted.

a zone in which the granite was highly weathered and sandy. Several attempts were necessary to get each sample because all attempts where insertion was difficult, due the presence of gravels or stones or when sample compaction was suspected, were systematically discarded.

As shown in Fig. 3, the trench cross-section showed a zone where the weathered granite appeared visually heterogeneous, with decimetric unweathered granite blocks (Geh). All 10 core samples were extracted from the zone $(\mathrm{Ge})$ where the texture and color of the weathered granite appeared homogeneous. The mean grain size of the different weathered granite types was determined by Legout (2006) from four replicates. The type corresponding to our samples had bulk densities ranging from 1.4 to $1.7 \mathrm{~g} \mathrm{~cm}^{-3}$, with 5 to $9 \%$ clay, 11 to $13 \%$ silt, and 70 to $82 \%$ sand.

\section{Laboratory Experiments}

The method of Wind (1968) was used to estimate the retention curves of undisturbed samples of the weathered granite. This method of experimentation is based on monitoring free evaporation from the surface of a presaturated undisturbed sample. The total mass of the sample and the matric potential $(b)$ at several depths are continually measured and recorded every $20 \mathrm{~min}$ by microtensiometers inserted at five depths (Fig. 4). The method is based on the principle of a dynamic measurement (Fig. 5). The principle is to use, at each measurement step, a function that approximates the volumetric moisture profile from the mean water content derived from the sample mass. The retention curve is thus constituted by the set of data pairs $[h(z, t), \theta(z, t)]$, where $h(z, t)$ is the matric potential and $\theta(z, t)$ is the moisture estimated at depth $z$ and time $t$ from the approximation function of the moisture profile. 


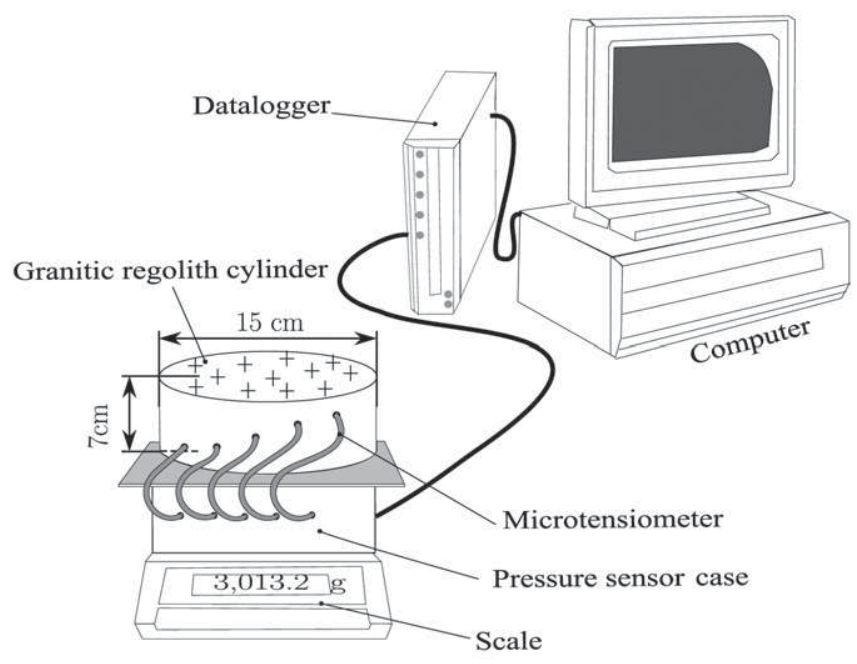

Fig. 4. Experimental device for matric potential and weighing humidity measurements (Wind method).
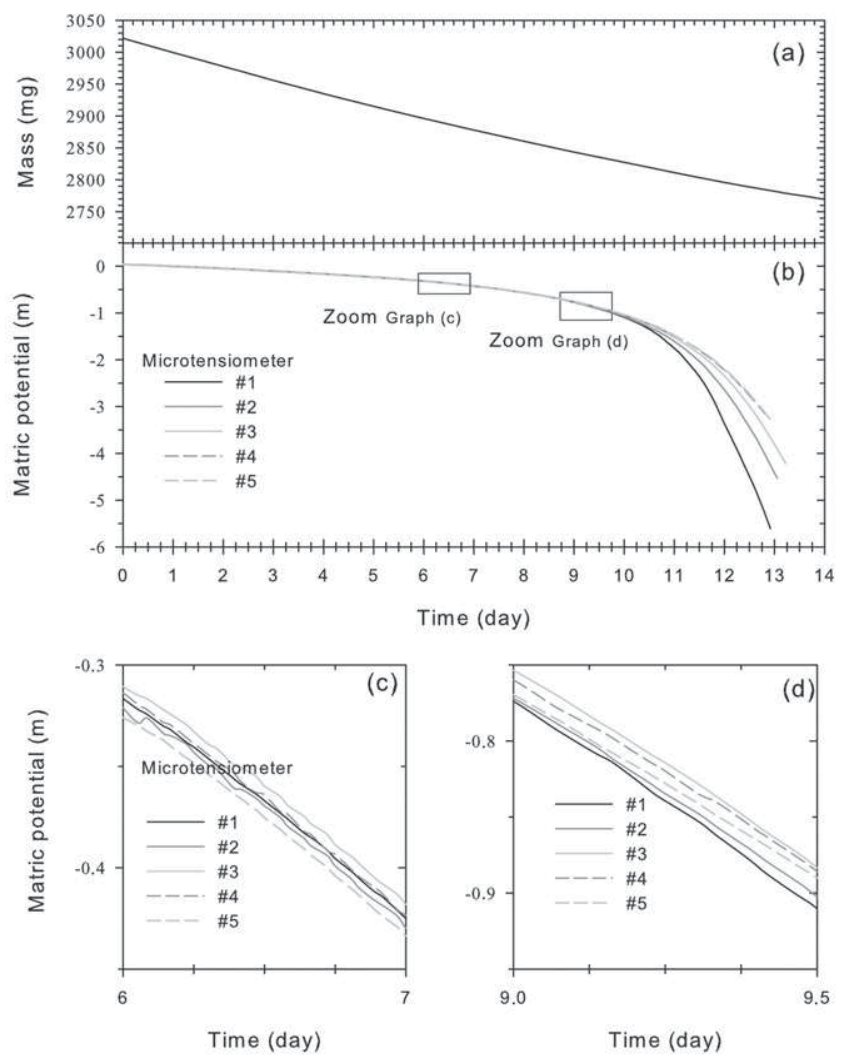

Fig. 5. Example of time series of (a) sample mass and (b) matric potential for the five tensiometers during a Wind experiment; (c) and (d) illustrate portions of the experiment where data were discarded.

This method was chosen because it does not require waiting for an equilibrium between the pressure applied and the water volume of the sample. In fact, Jones and Graham (1993) reported that one must wait several weeks to reach a state of equilibrium as a function of the degree of weathering and the potential applied to the sample.
The samples were progressively saturated with water from the bottom up in a bath of an aqueous solution of $\mathrm{KCl}$ to minimize air entrapment. Once placed on the experimental bench, the samples were equipped with five microtensiometers connected to pressure sensors to record pressure variability at different depths $(z)$ during the evaporation of water contained in the sample (Fig. 4). The microtensiometers were numbered 1 to 5 from the surface to the bottom of the sample, respectively. A balance (XS6001S Mettler Toledo) was used to follow the decrease in sample mass during the experiment. A datalogger connected to a computer allowed calibration of the pressure sensors before mounting the sample on the experiment bench and then recording the sample mass and the tension at the terminals of the pressure sensors during the experiment. The calibration consisted in building a linear relationship between water pressure and electric tension measured at the sensor terminal. Pressure was applied in a continuous pneumatic network (the real pressure was measured with precision sensors calibrated by an accredited laboratory) connected to all pressure sensors. The point control series were obtained every $5 \mathrm{kPa}$ from 0 to $80 \mathrm{kPa}$.

\section{Moisture Profile Approximation}

A moisture profile of the sample was estimated at each measurement step by fitting a van Genuchten function:

$\theta(z)=\theta_{\text {bot }}+\left(\theta_{\text {surf }}-\theta_{\text {bot }}\right)\left[\frac{1}{1+\left(a_{1} z\right)^{n_{1}}}\right]^{1-1 / n_{1}}$

where $\theta_{\text {surf }}$ is the water content at the level of the microtensiometer located at the surface and $\theta_{\text {bot }}$ is the water content of the deepest microtensiometer, $z$ is the depth from the surface of the sample, and $n_{1}$ and $a_{1}$ are fit parameters.

A numeric inversion method was used to determine the parameters of the retention curve from the measurements performed during the experiment. We applied this method with ESPAS 1.0 software (Mohrath et al., 1996). The quality of the fit depended on the ability of the model and the fitted parameters to reproduce the change in the mean water content of the sample. The mean water content was obtained from the mass of the sample recorded by the balance and the bulk density of the sample.

We used two criteria to evaluate the quality of the fit. The first criterion verified that the relation between the mean water content measured with the equipment and the water content estimated by the equation was linear and unambiguous. The second criterion verified that the differences between the observed and predicted water content values were $<0.0025 \mathrm{~cm}^{3} \mathrm{~cm}^{-3}$. To satisfy these two criteria, some values were excluded from the analysis, especially when the hydraulic gradient was not significant given the accuracy of the sensors $( \pm 3 \mathrm{~cm})$. This was frequently the case at the early stages of the experiment, as illustrated in Fig. $5 \mathrm{c}$ and $5 \mathrm{~d}$. 


\section{Numerical Estimation of the Water Retention Curve}

The set of data pairs $[h(z, t), \theta(z, t)]$ defined the retention curve of the sample. We fit the curves with the van Genuchten-Mualem equation:

$$
\theta(b)=\theta_{\mathrm{r}}+\left(\theta_{\mathrm{s}}-\theta_{\mathrm{r}}\right)\left[1+(\alpha|h|)^{n}\right]^{-m}
$$

where $\theta$ is soil water content, $\theta_{\mathrm{s}}$ is the saturated water content, $\theta_{\mathrm{r}}$ is the residual water content, $\alpha\left(>0 \mathrm{~cm}^{-1}\right)$ is an empirical parameter whose inverse is often referred to as the air-entry value or bubbling pressure, $n$ is a pore-size distribution parameter affecting the slope of the retention function, and $m$ is a parameter related to the asymmetry of the retention curve that equals $1-1 / n$ (Mualem's approximation).

The moisture value at saturation was fixed in Eq. [2] from the saturated sample mass before beginning the experiment; the other parameters were fitted by the Marquardt (1963) algorithm with the ESPAS 1.0 software (Mohrath et al., 1996). To calculate a mean retention curve representative of the sampled weathered granite, we used the computer code RETC (van Genuchten et al., 1991). All parameters were optimized: moisture at saturation $\left(\theta_{s}\right)$, residual moisture $\left(\theta_{\mathrm{r}}\right)$, and the terms $\alpha$ and $n$.

To compare the retention curves of the weathered granite samples with one another and with the various approaches used to estimate them, we calculated the quantity of free water $\left(\theta_{\mathrm{e}}\right)$. Free water is that which lies outside the field of attraction of solid particles and which is susceptible to move with gravity or pressure gradients (de Marsily, 1981). Thus, $\theta_{\mathrm{e}}$ was calculated as the difference between $\theta_{\mathrm{s}}$ and $\theta_{\mathrm{r}^{\prime}}$. For the same reasons, we determined the value of the matric potential $\left(\psi_{\mathrm{m}}\right)$ when the effective saturation $\left(S_{\mathrm{e}}\right)$ was equal to 0.5 :

$$
S_{\mathrm{e}}=\frac{\theta-\theta_{\mathrm{r}}}{\theta_{\mathrm{s}}-\theta_{\mathrm{r}}}
$$

\section{Soil Particle Size Approaches}

We used the UNSODA database (Nemes et al., 2001) to select water content measurements coupled with matric potential measurements for soil horizons with a particle size distribution equivalent to the weathered granite material that we studied. The experimental results extracted from the UNSODA database concerned only undisturbed samples with bulk densities ranging from 1.41 to $1.56 \mathrm{~g} \mathrm{~cm}^{-3}$, which correspond to the range of bulk densities of weathered granite types estimated by Legout et al. (2007). Also, only data from laboratory soildrying methods were compared with the mean retention curves of the weathered granite samples to eliminate differences due to hysteresis effects on the water retention curve. Finally, the results of five samples from the studies of Bruce et al. (1983), Dane et al. (1983), and Cassel and Sweeney (1976) were matched with the criteria.

\section{Hierarchical Pedotransfer Function}

We used the ROSETTA computer program (Schaap et al., 2001), which implements five hierarchical pedotransfer functions and allows the estimation of the van Genuchten (1980) water-retention parameters using texture and bulk density input data (Schaap et al., 2001). To determine pedotransfer functions, Schaap and Leij (1998) used three databases, those of Ahuja et al. (1985), de Rawls et al. (1982), and UNSODA. We used this program to generate the parameters of the retention curves of two materials having textures and bulk densities surrounding the values characterizing the weathered granite type we studied. From these two retention curves, we used the calculation code RETC again to calculate the mean retention curve and the retention curves delimiting the confidence interval of this mean curve.

\section{Weathering Index}

We collected from the literature the results of water-retention measurements for granite samples belonging to Index 6 in the Clayton and Arnold (1972) classification system. The results came from the studies of Hubbert et al. (2001b) and Jones and Graham (1993) on samples of granite rock from central California and Katsura et al. (2009) on samples of granite rock from northeastern Osaka, Japan. In the first two studies, samples were extracted on an outcrop and an excavated trench. In the last study, samples came from deep coring from the surface to a depth of $38 \mathrm{~m}$. To apply a matric potential to the samples, all three studies used a pressure plate according to the method of either Klute (1986) or Dane and Hopmans (2002).

\section{Results}

Of the 10 samples analyzed by the Wind method, only eight allowed description of a part of the retention curve that met the two fit criteria. The curve parameters are presented in Table 1 . The decrease in water content with the matric potential was monitored until the matric potential reached nearly $-580 \mathrm{~cm}$ for one sample (Fig. 5) and on average $-430 \mathrm{~cm}$. The value of the minimum potential reached during the experiment depended on the moment when the hydraulic continuity between the microtensiometers and the media was broken. The variability in the matric potential in the samples coincided with the range of values measured in situ by the tensiometers and at depths equal to those from which the samples were extracted. Nonetheless, the eight partial retention curves (Fig. 6) show that the range of validity is narrower for some of the retention curves obtained with the Marquardt algorithm.

The data retained for analysis allowed calculation of the parameter values for Eq. [2] that met the two fit criteria (Table 1). Moisture at saturation $\left(\theta_{s}\right)$ was close to total porosity values from the literature for Index 6 (Fig. 1), indicating that nearly all the pore space is accessible to water. Excluding Sample 3a, the mean water content at saturation was $34 \%(\mathrm{SD}=2.5 \%)$, the mean residual water content was $7 \%(\mathrm{SD}=2.6 \%)$, and the mean free water content was $27 \%(\mathrm{SD}=3.9 \%)$. 
Table 1. Values of the van Genuchten model parameters (saturated water content $\theta_{\mathrm{s}}$, residual water content $\theta_{\mathrm{r}}$, and fit parameters $\alpha$ and $n$ ) describing the water retention curves of weathered granite samples according to the Wind method and characteristic values of the free volumetric water content, defined as the difference between $\theta_{\mathrm{s}}$ and $\theta_{\mathrm{r}}\left(\theta_{\mathrm{e}}\right)$, the matric potential when effective saturation is $0.5\left(\psi_{\mathrm{m}}\right)$, and the free-water proportion, which moves along the water retention curve portion described with the Wind method $(M)$ at depths of 135 (four samples), 155 (three samples), and $167 \mathrm{~cm}$ (one sample) below the surface.

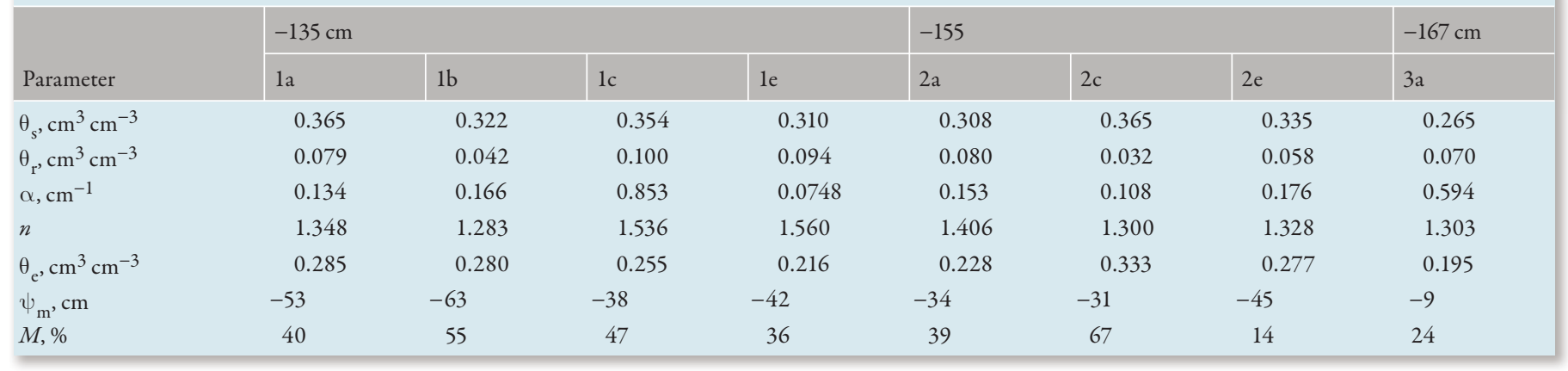

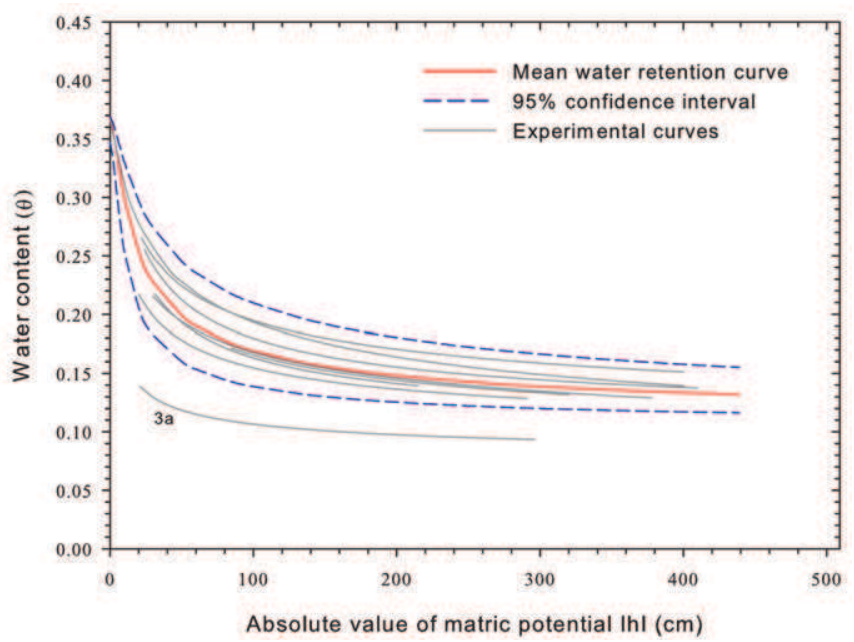

Fig. 6. Experimental water retention curves from weathered granite samples (gray lines). Mean water retention curve and confidence interval curves were fitted using the RETC computer code.

The quantity of free water in the weathered granite samples fell by $50 \%$ as soon as the matric potential approached approximately -40 $\mathrm{cm}$. This $\psi_{\mathrm{m}}$ value increased sharply with increasing sampling depth: $-49 \mathrm{~cm}(\mathrm{SD}=11.3 \mathrm{~cm})$ for samples extracted at $-135 \mathrm{~cm}$ below ground level, $-37 \mathrm{~cm}(\mathrm{SD}=7.4 \mathrm{~cm})$ for those extracted at $-155 \mathrm{~cm}$, and $-9 \mathrm{~cm}$ for the single sample extracted at $-167 \mathrm{~cm}$. This trend is not significant, however, given the small number of samples at each depth. The high $\psi_{\mathrm{m}}$ values indicate that a large proportion of the water in the weathered granite moves before the matric potential changes significantly. In other words, most water in the weathered granite samples was weakly connected to particles and could move easily.

On average, the percentage of free water $(M)$ that moves in the partial retention curves is only $40 \%$. The method applied to the weathered granite samples is therefore less robust for the part of the curve in which the water content is near saturation. Nearly all the curves intersect or are highly similar, except for Sample 3a, which
Table 2. Mean values and 95\% confidence intervals of the van Genuchten model parameters (saturated water content $\theta_{s}$, residual water content $\theta_{\mathbf{r}}$, and fit parameters $\alpha$ and $n$ ) and characteristic values of the free volumetric water content, defined as the difference between $\theta_{s}$ and $\theta_{\mathrm{r}}\left(\theta_{\mathrm{e}}\right)$ and the matric potential when effective saturation is $0.5\left(\psi_{\mathrm{m}}\right)$ describing the mean water retention curve and $95 \%$ confidence interval curves of weathered granite samples using the Wind method. Values were fitted with the RETC computer code (van Genuchten et al., 1991) from retention curves of weathered granite samples.

\begin{tabular}{l|ccc} 
& & \multicolumn{2}{c}{$95 \%$ confidence interval } \\
\cline { 3 - 4 } Parameter & Fitted mean & Lower limit & Upper limit \\
\hline$\theta_{\mathrm{s}}, \mathrm{cm}^{3} \mathrm{~cm}^{-3}$ & 0.367 & 0.347 & 0.369 \\
$\theta_{\mathrm{r}}, \mathrm{cm}^{3} \mathrm{~cm}^{-3}$ & 0.102 & 0.104 & 0.086 \\
$\alpha, \mathrm{cm}^{-1}$ & 0.118 & 0.159 & 0.075 \\
$n$ & 1.553 & 1.703 & 1.403 \\
$\theta_{\mathrm{e}}, \mathrm{cm}^{3} \mathrm{~cm}^{-3}$ & 0.265 & 0.243 & 0.283 \\
$\psi_{\mathrm{m}}, \mathrm{cm}$ & -27 & -15 & -70 \\
\hline
\end{tabular}

differs noticeably from the others. This difference can be explained by a higher value for parameter $\alpha$ and lower value for $\theta_{s}$ for this sample than for the others. When the matric potential falls below $-150 \mathrm{~cm}$ or when only an average of $25 \%$ of free water remains, the water content decreases little as the matric potential decreases.

The curve of Sample 3a was not included in the calculation of the parameters of the mean retention curve of the sampled weathered granite. Fitting was performed from 226 pairs of $h$ and $\theta$ values that came from the curves at regular intervals of $10 \mathrm{~cm}$. Figure 6 shows that the confidence interval of the mean retention curve does not cover the partial retention curve of Sample 3a. This confirms that the retention properties of Sample 3a differ significantly from those of the other samples.

The fitted parameter values and their $95 \%$ confidence intervals are given in Table 2. At the two limits of the confidence intervals, the free water content is relatively different $( \pm 4 \%)$. The $\psi_{\mathrm{m}}$ varies by a factor of nearly 5 from the lower to the upper limit. 

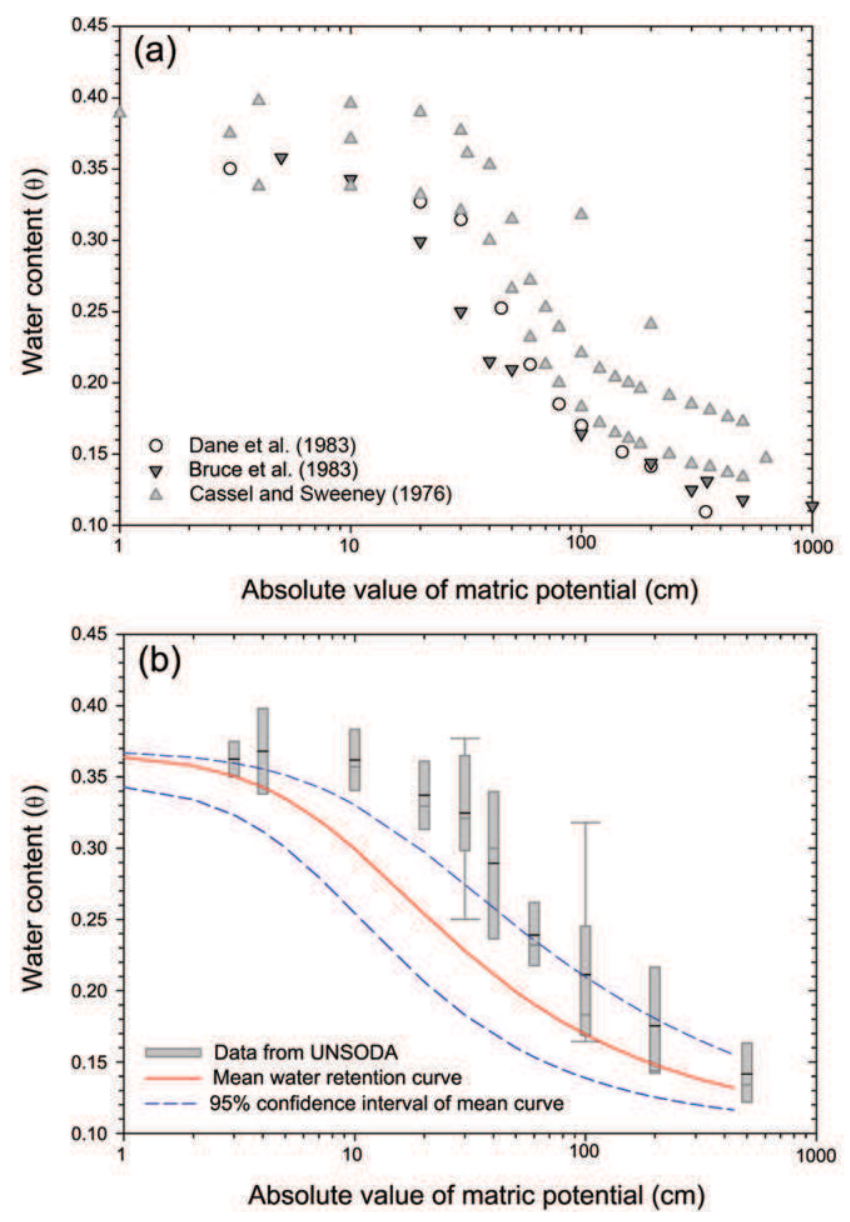

Fig. 7. (a) Scatterplot of data selected using particle size criteria in the UNSODA database; (b) mean water retention curve (red line) with confidence interval (dashed blue line) obtained with an experimental approach from weathered granite samples and compared with predictions of particle size approaches (box plots). Box plots show lower (bottom of box) and upper (top of box) quartiles, medians (gray band), means (black band), and possible extreme values (ends of whiskers).

\section{Soil Particle Size Distribution Approaches}

Although we selected undisturbed samples with restrictive criteria for particle size distribution (PSD), measuring methods, and bulk density, the cloud of points formed by the measurements of moisture and matric potential is stretched along the matric potential axis (Fig. 7a). This implies that the retention parameters vary among the samples. The means and upper and lower quartiles of water content were calculated for every matric potential, considering the five soil horizon samples collected from the UNSODA database. By overlaying these statistics with the mean retention curve of the weathered granite samples (Fig. $7 \mathrm{~b}$ ), we observed that the confidence interval of the mean retention curve of the weathered granite samples had the same order of magnitude as the scattering of data from the UNSODA database. For matric potentials smaller than $-80 \mathrm{~cm}$, water content values of samples from the UNSODA database almost completely cover the confidence interval of the mean retention curve of the weathered granite. Consequently, for matric potential values smaller than $-80 \mathrm{~cm}$, the water content mean values are not significantly different from those predicted by the mean retention curve of the weathered granite samples. For matric potentials larger than $-80 \mathrm{~cm}$, the mean water content of the soil samples from the UNSODA database was consistently larger than the upper limit of the confidence interval of the experimental mean retention curve for weathered granite.

\section{Pedotransfer Function Approaches}

The $\theta_{s}$ value predicted by the pedotransfer function (Table 3 ) was significantly larger than those measured for the weathered granite samples (Table 2). For the $\theta_{\mathrm{r}}$, the weathered granite samples had larger values. These differences were significant because there was no overlap in the ranges of predicted vs. observed water content values (Table 3). Consequently, the free water contents measured in the weathered granite samples were significantly smaller than those predicted by the pedotransfer function. Moreover, the shape of the retention curve predicted by the pedotransfer function showed strong differences with the mean curve of the weathered granite samples (Fig. 8). As for the PSD approaches, the water content for the retention curve predicted by the pedotransfer function is close to saturation and for matric potential values smaller than those for the mean retention curve of the weathered granite samples. This difference illustrates for the values of $\alpha$ and $n$ the deviation between those predicted by the pedotransfer function and those measured in the weathered granite samples (Table 3).

\section{Retention Properties of Similarly Weathered Granite}

Retention properties from the literature for weathered granite with the same weathering index vary greatly (Table 4; Fig. 9). For $\theta_{s}$, values range from 15 to $37 \%$, while those for $\theta_{\mathrm{r}}$ range from 6 to $24 \%$. The mean water retention curve of the weathered granite studied here lies in the upper part of the range of $\theta_{s}$ and the lower part of the range of $\theta_{\mathrm{r}}$. For $\theta_{\mathrm{e}}$, the range of the values of the weathered granite

Table 3. Mean values and $95 \%$ confidence intervals of the van Genuchten model parameters (saturated water content $\theta_{s}$, residual water content $\theta_{\mathbf{r}}$, and fit parameters $\alpha$ and $n$ ) and characteristic values of the free volumetric water content, defined as the difference between $\theta_{\mathrm{s}}$ and $\theta_{\mathrm{r}}\left(\theta_{\mathrm{e}}\right)$ and the matric potential when effective saturation is $0.5\left(\psi_{\mathrm{m}}\right)$ describing the mean water retention curve and $95 \%$ confidence interval curves of weathered granite samples using a pedotransfer function based on soil with an equivalent particle size distribution. Values were fitted with the RETC computer code (van Genuchten et al., 1991).

\begin{tabular}{lccc} 
& & \multicolumn{2}{c}{$95 \%$ confidence interval } \\
\cline { 3 - 4 } Parameter & Fitted mean & Lower limit & Upper limit \\
\hline$\theta_{\mathrm{s}}, \mathrm{cm}^{3} \mathrm{~cm}^{-3}$ & 0.401 & 0.396 & 0.407 \\
$\theta_{\mathrm{r}}, \mathrm{cm}^{3} \mathrm{~cm}^{-3}$ & 0.047 & 0.055 & 0.040 \\
$\alpha, \mathrm{cm}^{-1}$ & 0.038 & 0.074 & 0.041 \\
$n$ & 1.749 & 1.827 & 1.671 \\
$\theta_{\mathrm{e}}, \mathrm{cm}^{3} \mathrm{~cm}^{-3}$ & 0.354 & 0.314 & 0.367 \\
$\psi_{\mathrm{m}}, \mathrm{cm}$ & -61 & -50 & -76
\end{tabular}




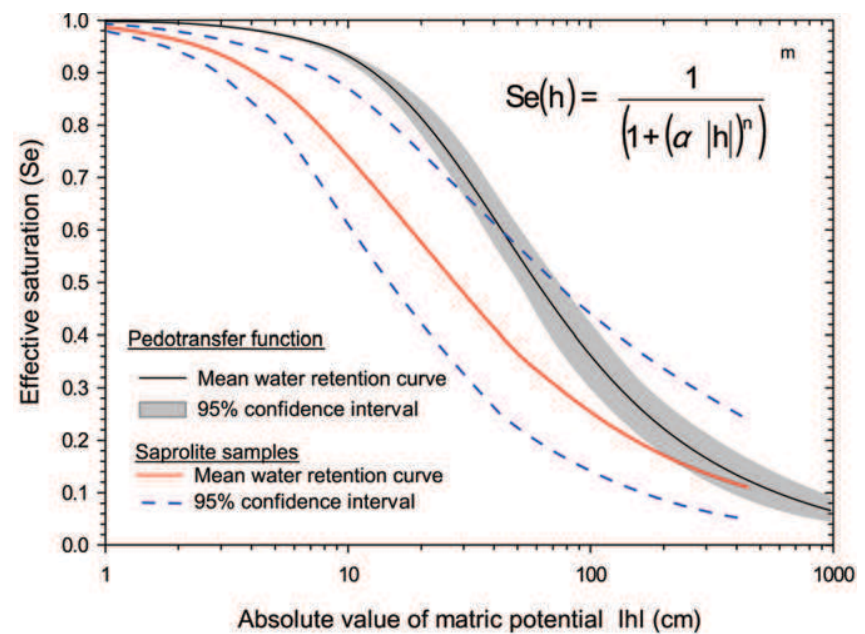

Fig. 8. Weathered granite samples mean retention curve (red line) and confidence interval (dashed blue lines) compared with the water retention curve predicted by a ROSETTA pedotransfer function (black line).

Table 4. Characteristic values of the free volumetric water content, defined as the difference between $\theta_{s}$ and $\theta_{r}\left(\theta_{e}\right)$ and the matric potential when effective saturation is $0.5\left(\psi_{\mathrm{m}}^{\mathrm{r}}\right)$ and specific water contents (saturated, $\theta_{s}$, and residual, $\theta_{\mathrm{r}}$ ) of weathered granite from this and other studies.

\begin{tabular}{|c|c|c|c|c|}
\hline \multirow[t]{2}{*}{ Study } & $\theta_{\mathrm{s}}$ & $\theta_{\mathrm{r}}$ & $\theta_{\mathrm{e}}$ & \multirow{2}{*}{$\begin{array}{l}\psi_{\mathrm{m}} \\
\mathrm{cm}\end{array}$} \\
\hline & \multicolumn{3}{|c|}{$-\mathrm{cm}^{3} \mathrm{~cm}^{-3}$} & \\
\hline Katsura et al. (2009) $\dagger$ & 0.291 & 0.244 & 0.047 & -29 \\
\hline Hubbert et al. (2001b) $\neq$ & 0.368 & 0.064 & 0.305 & -99 \\
\hline Jones and Graham $(1993) \neq \S$ & 0.200 & 0.082 & 0.118 & -89 \\
\hline $\begin{array}{l}\text { Jones and Graham (1993), } \\
\text { San Bernardino } \neq\end{array}$ & 0.149 & 0.062 & 0.087 & NDg \\
\hline $\begin{array}{l}\text { Jones and Graham } \\
\text { (1993), San Jacinto } \neq\end{array}$ & 0.270 & 0.084 & 0.186 & ND \\
\hline This study & 0.367 & 0.102 & 0.265 & -27 \\
\hline \multicolumn{5}{|c|}{$\begin{array}{l}\text { † Sampling by deep coring. } \\
\text { † Sampling from a soil pit. } \\
\text { \& Values of an individual sample from San Bernardino. } \\
\text { g ND, not determined. }\end{array}$} \\
\hline
\end{tabular}

samples studied here (Table 1) has the same order of magnitude as that from the literature. The value of $\psi_{\mathrm{m}}$ from the literature is lower than that of the weathered granite samples studied. Unlike for the water content values, for the values of $\psi_{m}$, the study of Katsura et al. (2009) had values closest to our results.

The results we obtained for the weathered granite samples were overall of the same order of magnitude as those obtained from samples extracted using the same method (Hubbert et al., 2001b; Jones and Graham, 1993). Nonetheless, there is a large disparity in the results, even though the weathered granite samples belonged to the same weathering class.

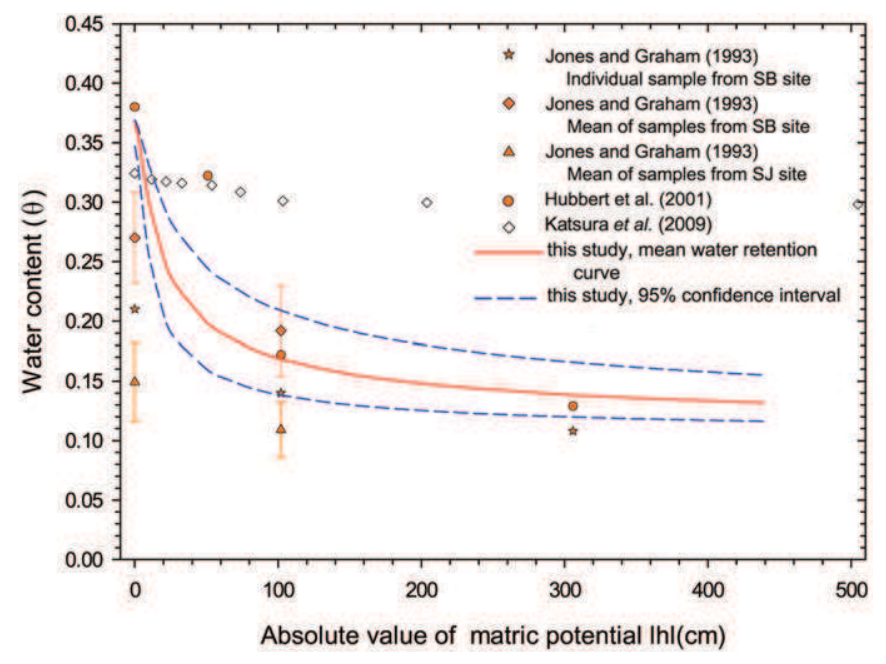

Fig. 9. Comparison between the mean water retention curve for weathered granite samples and water content-matric potential, $\theta(b)$, pair measurements from other weathered granite bedrocks with the same weathering index (Index 6). In Jones and Graham (1993), available values were averages from the San Jacinto (SJ) or San Bernardino (SB) sites, and one set of values from one individual sample from the $\mathrm{SB}$ site is also given.

\section{Discussion Water Retention Characteristics}

For undisturbed weathered granite samples, the Wind (1968) method appears interesting to describe the portion of the retention curve in which the water content is the lowest (Fig. 6). In addition, examination of an apparently homogenous weathered granite (Fig. 3) revealed that the shapes of the retention curves from samples extracted from different locations were similar and nearly parallel to each other. The mean water retention curve of the weathered granite exhibited a large change in $\theta$ for $h$ values from 0 to $-100 \mathrm{~cm}$ but little change below $-100 \mathrm{~cm}$ (Fig. 6). We can infer that the weathered granite contained distinguishable macropores and micropores. Variability can be observed, however, between the measured water retention curves. The variability may have many origins. Differences in the relative degree of weathering might be one of them. Even if all the collected samples were classified as Index 6 of Clayton and Arnold's weathering classification, slight differences in weathering degree cannot be excluded. This could mean that this index is not accurate enough to discriminate water retention properties. Another origin of this variability might be the differences in the compaction of the weathered granite by overburden forces, depending on sampling depth. The rest of the discussion will focus on comparison of our results with soils of the same texture and with results obtained for similar materials (weathered granite).

\section{Utility of Pedotransfer Functions}

Indirect estimation methods (PSD and pedotransfer function approaches) used for soils did not appear adequate to predict the retention curve of the weathered granite samples in this study. Comparison of the mean retention curve of the weathered granite 
derived from the Wind experiment and the curves obtained from the PSD approach and pedotransfer functions reveal strong differences (Fig. $7 \mathrm{~b}$ and 8 ).

The value of $\theta_{\text {s }}$ predicted by the pedotransfer function (Table 3 ) is larger than that measured in the weathered granite samples (Table 2). This difference can be explained by the degree of weathering of the weathered granite, which is a little higher than that of a soil. Porosity being highly correlated with the degree of weathering for weathered granite (Fig. 1), for a given grain size, soil contains more water than weathered granite. The relation between $\theta_{\mathrm{e}}$ and $\theta_{\mathrm{s}}$ indicates that $72 \%$ of the water contained in a sample of weathered granite can be mobilized. For a soil of equivalent texture, this relation is $88 \%$. This difference suggests that the micropore volume containing immobile water is proportionally larger in a weathered granite than in a soil of equivalent texture, which has a larger volume of macropores that contribute more to the quantity of free water.

The difference between the values of $n$ in Eq. [2] for the mean retention curve of the weathered granite samples (Table 2) and that predicted by the pedotransfer function (Table 3 ) is not significant because the confidence intervals of the values of $n$ overlap. Nonetheless, the value of $\alpha$ (Tables 2 and 3 ), corresponding to the inverse of the air-entry pressure, is significantly larger for the weathered granite samples because the confidence intervals do not overlap. Comparing the retention curves linking the effective saturation $\left(S_{\mathrm{e}}\right)$ with the matric potential $(b)$, shows the effect of $\alpha$ and the shape of the retention curves (Fig. 8). With the pedotransfer function, the water content remains close to saturation for matric potential values between -1 and $-10 \mathrm{~cm}$, while for a matric potential of $-10 \mathrm{~cm}$, the retention curve of weathered granite indicated that the volume of free water in the sample represented no more than $75 \%$ of the volume contained in the sample when it was saturated. The difference between the water content values predicted by the two curves remained significant until the matric potential fell below $-30 \mathrm{~cm}$.

\section{Can the Weathering Index be Used to Derive the Water Retention Curve?}

The weathering class did not distinguish weathered granite samples sufficiently to infer their retention properties. Our results showed relatively large differences between the retention properties of the weathered granite samples in this study (Table 2) and those reported in the few published studies on the subject (Table 4). These differences could be explained by variations in the mineral composition and size of crystals that make up the original rock. In fact, the minerals do not weather at the same speed nor in the same way, some producing clays and others producing sandy or silty particles. The mineral composition of the original substrate certainly has an important influence on the texture, in particular on the clay content, of the weathered material and thus an influence on the retention properties. The mineral composition of the original rock determines the ability of weathering agents to modify the rock's porosity and retention capacity.
The values obtained for the sample studied by Katsura et al. (2009) clearly differ from those obtained for all the other samples (Fig. 9), in particular for matric potential values below $-100 \mathrm{~cm}$. The coring technique used is particular to the samples extracted by Katsura et al. (2009) and could have modified the sample structure. Thus, the method used to extract samples could lead to modifications of the material that have consequences on the retention curve of the sample.

\section{Conclusions}

The study showed that the Wind method can be used to measure the retention curve of undisturbed samples of weathered granite. This method describes the portion of the retention curve in which water contents are relatively low. Regardless of the approach used to compare our results to those obtained for soils with similar texture, we noted that the weathered granite had a retention curve notably different from that of a soil. This difference was larger at high matric potentials.

The moisture values predicted by the retention curve for the weathered granite samples approached values that were obtained for samples of granite with the same degree of weathering and different origins as long as the samples were extracted with the same method. The weathering classification of Clayton and Arnold (1972), however, is not accurate enough to predict hydrodynamic parameters. Thus, the experimental approach remains, for the moment, the only way to obtain a reliable estimate of the hydrodynamic properties of these materials; however, this approach is exacting regarding both extraction of samples and laboratory procedure. Consequently, given the importance of weathered granite layers in water storage and transport processes, it is necessary to develop databases that bring together the experimental results of measurements of the hydrodynamic properties of this type of material in order to assess if there is a need to develop specific functions for this kind of material. To develop predictive relations, the samples studied must be defined with variables that are simple to measure, suitable, and contain sufficient criteria to distinguish different types of weathered granite. An extension of this work would be to characterize the hydrodynamic properties of all weathered bedrocks, not only granitic. If the relations found for weathered bedrocks appears specific compared with that found for soils, the results of these studies could be regrouped into a specific database similar to that already existing for soils, which currently has no equivalent for weathered bedrocks.

\section{Acknowledgments}

This research was supported by grants from the following French programs: ORE AgrHyS, SOERE RBV (Allenvi), and ANR ACASSYA (ANR-08-STRA-01).

\section{References}

Ahuja, L.R., J.W. Naney, and R.D. Williams. 1985. Estimating soil water characteristics from simpler properties or limited data. Soil Sci. Soc. Am. J. 49:1100-1105. doi:10.2136/sssaj1985.03615995004900050005x

Baynes, J., and W. Dearman. 1978. The microfabric of a chemically weathered granite. Bull. Eng. Geol. Environ. 18:91-100.

Béchennec, F., B. Hallégouët, and D. Thiéblemont. 1999. Notice explicative, Carte géologique de France (1/50000), feuille de Quimper (346). Bureau de Recherches Géologiques et Minières, Orléans, France. 
Begonha, A., and M.A. Sequeira Braga. 2002. Weathering of the Oporto granite: Geotechnical and physical properties. Catena 49:57-76. doi:10.1016/ S0341-8162(02)00016-4

Brace, W.F., J.B. Walsh, and W.T. Frangos. 1968. Permeability of granite under high pressure. J. Geophys. Res. 73:2225-2236. doi:10.1029/ JB073i006p02225

Bruce, R.R., J.H. Dane, V.L. Quisenberry, N.L. Powell, and A.W. Thomas. 1983. Physical char-acteristics of soils in the southern region: Cecil series. Southern Coop. Ser. Bull. 267. Univ. of Georgia Agric. Exp. Stn., Athens.

Cassel, D.K., and M.D. Sweeney. 1976. In situ soil water holding capacities of selected North Dakota soils. Bull. 495. North Dakota State Univ. Agric. Exp. Stn., Fargo.

Clayton, J.L., and J.F. Arnold. 1972. Practical grain size, fracturing density and weathering clas-sification of intrusive rocks of Idaho batholith. Gen. Tech. Rep. INT-2. U.S. For. Serv., Intermountain For. Range Exp. Stn., Ogden, UT

Cosenza, B. 2005. Tomographie de résistivité electrique 3D sur le bassin versant de Kerrien (Finistère, France): Comparaison avec d'autres méthodes géophysiques (TRE 2D, EM31 et RMP). UMR 7619 Sisyphe. Univ. Pierre et Marie Curie, Paris.

Dane, J.H., J.M. Cassel, and W.L. Davidson. 1983. Physical characteristics of soils of the south-ern region: Troup and Lakeland series. Southern Coop. Ser. Bull. 262. Alabama Agric. Exp. Stn., Auburn, AL.

Dane, J.H., and J.W. Hopmans. 2002. Water retention and storage: Laboratory. In: J.H. Dane and G.C. Topp, editors, Methods of soil analysis. Part 4. Physical methods. SSSA Book Ser. 5. SSSA, Madison, WI. p. 688-690.

de Marsily, G. 1981. Hydrogéologie quantitative. Masson, Paris.

Gokceoglu, C., K. Zorlu, S. Ceryan, and H.A. Nefeslioglu. 2009. A comparative study on indi-rect determination of degree of weathering of granites from some physical and strength parameters by two soft computing techniques. Mater. Charact. 60:1317-1327. doi:10.1016/j.matchar.2009.06.006

Graham, R.C., A.M. Rossi, and K.R. Hubbert. 2010. Rock to regolith conver sion: Producing hospitable substrates for terrestrial ecosystems. GSA Today 20:4-9. doi:10.1130/GSAT57A.1

Haria, A.H., and P. Shand. 2004. Evidence for deep sub-surface flow routing in forested upland Wales: Implications for contaminant transport and stream flow generation. Hydrol. Earth Syst. Sci. 8:334-344. doi:10.5194/hess-8-334-2004

Hubbert, K.R., J.L. Beyers, and R.C. Graham. 2001a. Roles of weathered bedrock and soil in seasonal water relations of Pinus jeffreyi and Arctostaphylos patula. Can. J. For. Res. 31:1947-1957.

Hubbert, K.R., R.C. Graham, and M.A. Anderson. 2001b. Soil and weathered bedrock: Compo-nents of a Jeffrey pine plantation substrate. Soil Sci. Soc. Am. J. 65:1255-1262. doi:10.2136/sssaj2001.6541255x

Johnson-Maynard, J., M.A. Anderson, S. Green, and R.C. Graham. 1994. Physical and hydraulic properties of weathered granitic rock in southern California. Soil Sci. 158:375-380. doi:10.1097/00010694-199411000-00009

Jones, D.P., and R.C. Graham. 1993. Water-holding characteristics of weathered granitic rock in chaparral and forest ecosystems. Soil Sci. Soc. Am. J. 57:256-261. doi:10.2136/sssaj1993.03615995005700010044x

Katsura, S., K. Kosugi, T. Mizutani, and T. Mizuyama. 2009. Hydraulic properties of variously weathered granitic bedrock in headwater catchments. Vadose Zone J. 8:557-573. doi:10.2136/vzj2008.0142

Katsura, S., K. Kosugi, N. Yamamoto, and T. Mizuyama. 2006. Saturated and unsaturated hy-draulic conductivities and water retention characteristics of weathered granitic bedrock. Vadose Zone J. 5:35-47. doi:10.2136/ vzj2005.0040

Kew, G., and R. Gilkes. 2006. Classification, strength and water retention char acteristics of later-itic regolith. Geoderma 136:184-198. doi:10.1016/j. geoderma.2006.03.025

Klute, A. 1986. Water retention: Laboratory methods. In: A. Klute, editor Methods of soil anal-ysis. Part 1. 2nd ed. Agron. Monogr. 9. ASA and SSSA, Madison, WI. p. 687-734.

Legchenko, A., J.M. Baltassat, A. Bobachev, C. Martin, H. Robain, and J.M. Vouillamoz. 2004. Magnetic resonance sounding applied to aquifer characterization. Ground Water 42:363-373. doi:10.1111/j.1745-6584.2004. tb02684.x

Legout, C. 2006. Étude des mécanismes hydrologiques et biogéochimiques de la recharge des nappes à surface libre. In: Sciences de la terre. Univ. de Rennes, Rennes, France.

Legout, C., J. Molénat, L. Aquilina, C. Gascuel-Odoux, M. Faucheux, Y. Fauvel, and T. Bariac. 2007. Solute transfer in the unsaturated zone-groundwater continuum of a headwater catch-ment. J. Hydrol. 332:427-441. doi:10.1016/j.jhydrol.2006.07.017
Legout, C., J. Molénat, S. Lefebvre, P. Marmonier, and L. Aquilina. 2005. Investigation of bio-geochemical activities in the soil and unsaturated zone of weathered granite. Biogeochemistry 75:329-350. doi:10.1007/s10533005-0110-0

Lin, W., M. Takahashi, K. Nishida, and M. Zhang. 1999. Aquivalent channel models for perme-ability estimation and their application to sedimentary rocks. (In Japanese.) J. Jpn. Soc. Eng. Geol. 39:533-539. doi:10.5110/jjseg.39.533

Marquardt, D.W. 1963. An algorithm for least-squares estimation of nonlinear parameters. SIAM J. Appl. Math. 11:431-441. doi:10.1137/0111030

Martin, C., L. Aquilina, C. Gascuel-Odoux, J. Molénat, M. Faucheux, and L. Ruiz. 2004. Sea-sonal and interannual variations of nitrate and chloride in stream waters related to spatial and temporal patterns of groundwater concentrations in agricultural catchments. Hydrol. Process-es 18:1237-1254. doi:10.1002/hyp.1395

Martin, C., J. Molénat, C. Gascuel-Odoux, J.M. Vouillamoz, H. Robain, L. Ruiz, et al. 2006. Modelling the effect of physical and chemical characteristics of shallow aquifers on water and nitrate transport in small agricultural catchments. J. Hydrol. 326:25-42. doi:10.1016/j.jhydrol.2005.10.040

Mohrath, D., P. Bertuzzi, and L. Bruckler. 1996. Méthode de Wind: Guide d'utilisation du logi-ciel, version1. Rapport Technique Interne. INRA-CSE, Avignon, France.

Molénat, J. 2008. Hydrologie et transfert de substances dissoutes dans les aquifères superficiels. Univ. de Rennes, Rennes, France.

Molénat, J., C. Gascuel-Odoux, P. Davy, and P. Durand. 2005. How to model shallow water-table depth variations: The case of the Kervidy-Naizin catchment, France. Hydrol. Processes 19:901-920. doi:10.1002/hyp.5546

Nemes, A., M.G. Schaap, F.J. Leij, and J.H.M. Wösten. 2001. Description of the unsaturated soil hydraulic database UNSODA version 2.0. J. Hydrol. 251:151-162. doi:10.1016/S0022-1694(01)00465-6

Neuzil, C.E. 1986. Groundwater flow in low-permeability environments. Water Resour. Res. 22:1163-1195. doi:10.1029/WR022i008p01163

Rawls, W.J., D.L. Brakensiek, and K.E. Saxton. 1982. Estimation of soil water properties. Trans. ASAE 25:1316-1320.

Rouxel, M., J. Molénat, L. Ruiz, C. Legout, M. Faucheux, and C. Gascuel-Odoux 2011. Season-al and spatial variation in groundwater quality along the hillslope of an agricultural research catchment (western France). Hydrol. Processes 25:831-841. doi:10.1002/hyp.7862.

Ruiz, L., M.R.R. Varma, M.S.M. Kumar, M. Sekhar, J.C. Marechal, M. Descloitres, et al. 2010. Water balance modelling in a tropical watershed under deciduous forest (Mule Hole, India): Regolith matric storage buffers the groundwater recharge process. J. Hydrol. 380:460-472. doi:10.1016/j.jhydrol.2009.11.020

Schaap, M.G., and F.J. Leij. 1998. Database-related accuracy and uncertainty of pedotransfer functions. Soil Sci. 163:765-779. doi:10.1097/00010694199810000-00001

Schaap, M.G. F.J. Leij, and M.Th, van Genuchten, 2001. ROSETTA: A computer program for estimating soil hydraulic parameters with hierarchical pedotransfer functions. J. Hydrol. 251:163-176. doi:10.1016/ S0022-1694(01)00466-8

Schwinning, S. 2010. The ecohydrology of roots in rocks. Ecohydrology 3:238-245.

Thuro, K., and M. Scholz. 2003. Deep weathering and alteration in granites: A product of cou-pled processes. In: GeoProc 2003, International Conference on coupled T-H-M-C Processes in Geosystems: Fundamentals, Modelling Experiments and Applications. R. Inst. of Technol. (KTH), Stockholm, Sweden. p. 13-15.

van Genuchten, M.Th. 1980. A closed-form equation for predicting the hydraulic conductivity of unsaturated soils. Soil Sci. Soc. Am. J. 44:892-898. doi:10.2136/sssaj1980.03615995004400050002x

van Genuchten, M.Th., F.J. Leij, and S.R. Yates. 1991. The RETC code for quantifying the hy-draulic functions of unsaturated soils, version 1.0. EPA Rep. 600/2-91/065. U.S. Salinity Lab., Riverside, CA.

Wind, G.P. 1968. Capillary conductivity data estimated by a simple method. In: P.E. Rijtema and $\mathrm{H}$. Wassink, editors, Water in the unsaturated zone: Proceedings of the Wageningen Symposium. 19-25 June 1966. Vol. 1. IASH, Gentbrugge, Belgium. p. 181-191.

Zhao, J., B. Broms, Y. Zhou, and V. Choa. 1994. A study of the weathering of the Bukit Timah granite: Part A. Review, field observations and geophysical survey. Bull. Eng. Geol. Environ. 49:97-106. 